\title{
Hasil Cek Plagiasi
}

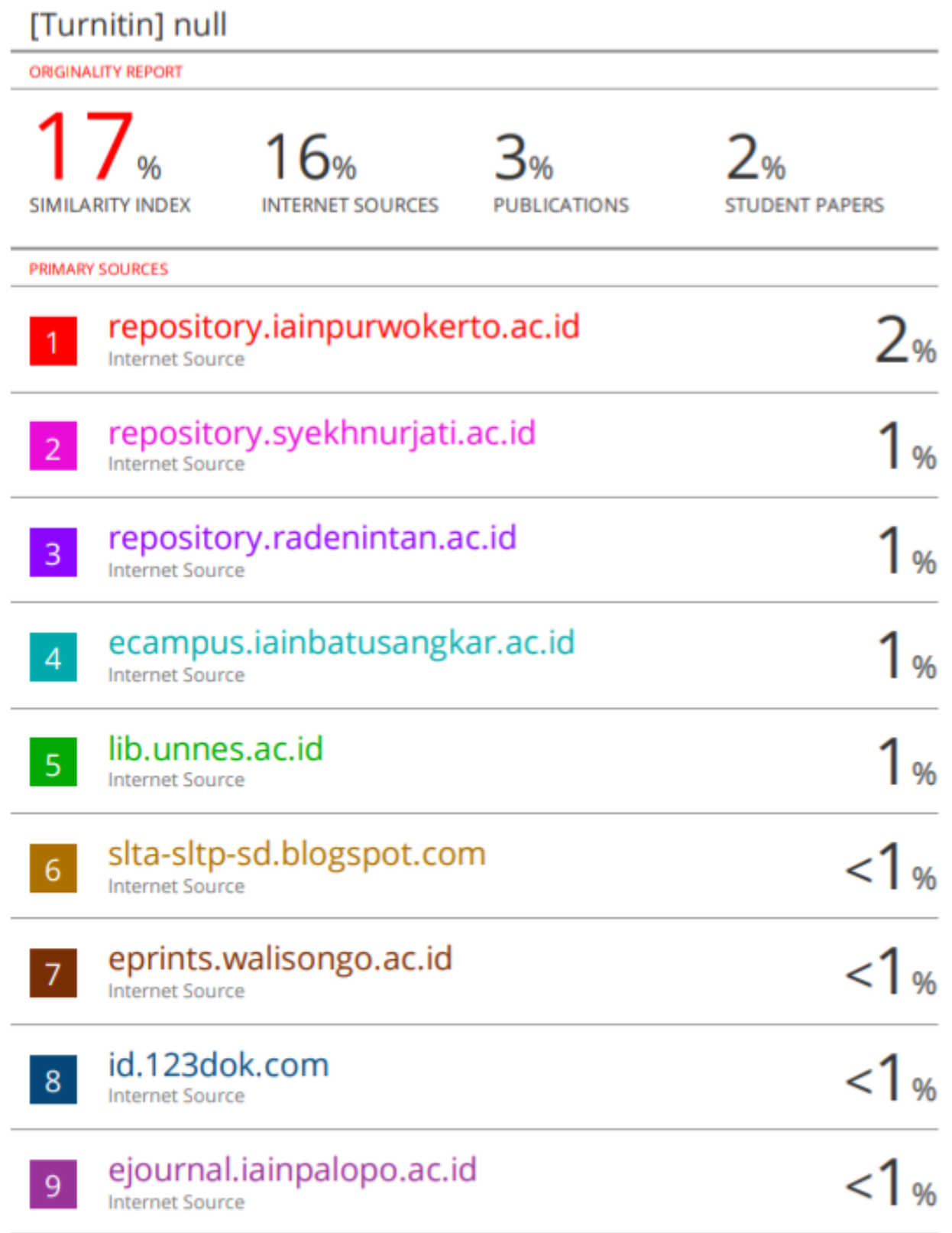

